\title{
Multi-Parametric Prostate MRI
}

\author{
Samuel Aronson* \\ Department of Urology, McGill University, Canada
}

Submission: February 14, 2017; Published: February 22, 2017

*Corresponding author: Samuel Aronson, Assistant Professor, Department of Urology, McGill University, Canada, Email: samuelaronson@hotmail.com

\section{Editorial}

Diagnosing prostate cancer was advanced with PSA. However, the premature and extensive use of PSA within on-targeted biopsy brought with it over diagnosis and over treatment. Urology is still redefining the diagnostic role of PSA and continues to study which prostate cancers are best monitored, treated or which kind of treatment.

For the first time in medical history the prostate can now be detailed imaged-external and internal anatomy, the restriction of water diffusion among cells and the micro vasculature.

Prostate MRI is a complex imaging biomarker which is able to initially assess and later be used as a baseline to monitor prostates. Prostate MRI requires a learning and experience curve

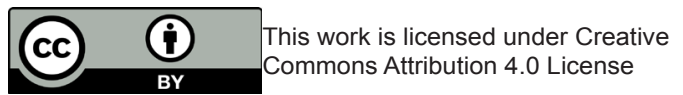

by Radiologist and Urologist. In capable hands a high quality prostate MRI can diagnose significant cancers much earlier and more precisely than PSA and other biomarkers as well as characterize and locally stage the tumor. The challenge in the clinical use of prostate MRI is to avoid the mistakes made with PSA and non-targeted biopsy- unessential biopsies, biopsies missing or inaccurately defining significant cancers and diagnosing not aggressive cancers. Prostate cancer treatments many times were inexact without detailed imaging. When expertly used prostate MRI is an important accurate tool in prostate cancer screening, biopsy, diagnosis, treatment selection/planning, post treatment evaluation for residual or recurrent cancer, surveillance and further understanding the natural history of prostate cancer, $\mathrm{BPH}$ and prostatitis.

\section{Your next submission with Juniper Publishers will reach you the below assets}

- Quality Editorial service

- Swift Peer Review

- Reprints availability

- E-prints Service

- Manuscript Podcast for convenient understanding

- Global attainment for your research

- Manuscript accessibility in different formats

( Pdf, E-pub, Full Text, Audio)

- Unceasing customer service

Track the below URL for one-step submission https://juniperpublishers.com/online-submission.php 